\title{
Country or Brand: What Matters to Younger Millennials?
}

\author{
Sergio Garrido Moraes ${ }^{1}$ \\ garridomestrado@gmail.com | (100000-0002-7115-3130 \\ Vivian Iara Strehlau ${ }^{1}$ \\ vstrehlau@espm.br | (D) 0000-0002-5352-4284
}

\begin{abstract}
Our objective is to compare the effects of country of origin (COO) and brand on Younger Millennials' (YM) willingness to buy global brands. We chose the United States, because it is the country of origin for the most valuable global brands. We approached Apple, Levi's, and McDonald's because they are iconic brands both in the US and globally. We tested constructs related to the country of origin and brand and then conducted a survey with 367 YM (17-23 years old) as potential brand consumers. We applied a structural equation model to analyze the impacts of these constructs on their willingness to buy. Results indicate that the way YM connect themselves to the brand is more important than the way they perceive or feel about the brand's country of origin. We studied real brands within their target market and, in a current context, translated constructs for application in day-to-day consumer situations, while seeking discoveries that can be widely applied in the field of international marketing.
\end{abstract}

KEYWORDS

Country of origin; Global brands; Generation

${ }^{1}$ Escola Superior de Propaganda e Marketing (ESPM), São Paulo, SP, Brasil

Received: 03/13/2019.

Revised: 07/04/2019.

Accepted: 08/27/2019.

Published Online: 03/23/2020.

DOI: http://dx.doi.org/10.15728/bbr.2020.17.3.2 
BBR

17

276

\section{INTRODUCTION}

The overall objective of this paper is to compare the effect of issues relating to country of origin (COO) and brand on Younger Millennials' willingness to buy global brands.

The effects of COO image on product acceptance and sales volume in foreign countries has intrigued market researchers since Schooler (1965) concluded that the attitude toward the people of a nation is related to prejudice against the products of that country.

However, the latest contributions to the literature on the COO effect criticized the dominant research approaches in the field, questioning the importance of country of origin (Samiee, Shimp, \& Sharma, 2005), its relevance (Usunier, 2006), the design of the research environment (Samiee, 2010), the emphasis on cognitive rather than affective aspects (Roth \& Diamantopoulos, 2009), the lack of market segmentation (Roth \& Diamantopoulos, 2010; Samiee, 2010), the relationship between COO concepts and brand nationality, the lack of a theoretical basis (Samiee, 2011), consumer accuracy in recognizing brand origin, the importance given to this knowledge at the time of purchase decisions (Samiee et al., 2005; Usunier, 2011), the lack of consideration of the global or local brand origin (although most studies are based on cross-national samples) (Riefler, 2012), and the failure to explicitly present the conceptual definition of country of origin or image (Carneiro \& Faria, 2016). As a result, Lu, Heslop, Thomas, and Kwan (2016) note that the influence of country image $(\mathrm{CI})$ articles has been decreasing, as well as their rate of publication in top-tier journals.

Some authors, however, claim that the COO effect would still be relevant, since it would affect consumers' attitudes toward a brand, even if they do not know the brand's origin (Magnusson, Westjohn, \& Zdravkovic, 2011), or that the COO effect would still be an important driver for building brand image and would affect purchase intentions, even if indirectly (Diamantopoulos, Schlegelmilch, \& Palihawadana, 2011). Furthermore, several studies associate country of origin with global brands, particularly in emerging countries (Akram, Merunka, \& Akram, 2011; Swoboda, Pennemann, \& Taube, 2012; Zbib, Wooldridge, Ahmed, \& Benlian, 2010), or with product evaluation in specific age groups (Zdravkovic, 2013). At the same time, CI research is becoming less US-centric and more sophisticated in methodology, evaluating more diverse product categories (Lu et al., 2016). Research on the topic has not yet reached saturation and is still relevant, both academically and managerially (Carneiro \& Faria, 2016). However, studying the $\mathrm{COO}$ effect without considering brand-related characteristics, at least regarding consumer goods, and some services, is no longer appropriate.

This study aims to evaluate the strength of country of origin and brand characteristics on Younger Millennials' willingness to buy global brands in a situation closer to the so-called "real world." There was concern about the consumer decision process on one hand and companies' marketing strategies on the other. To this end, real brands were studied, within their target market in a current context, translating constructs for application in day-to-day consumer situations and seeking findings that could be widely applied in the context of international marketing.

The United States was chosen for two reasons. First, the U.S. is a country that arouses conflicting feelings in consumers ranging from love to hate and from animosity to admiration, with all sometimes found in the same person (Russell, Russell, \& Klein, 2011). Second, it is the country of origin of the most valuable global brands (Interbrand, 2018), with high American origin recognition (Russell et al., 2011), involving symbolic values related to the identity of the United States in communicating with their target audiences (Martin, 2007). In addition, these brands 
are highly consumed by young people, the segment of interest in this study. The US is the study object, but the research was conducted with young Brazilian consumers. The US brands (Apple, Levi's, McDonald's) are very well-known, in order to eliminate lack of familiarity with the brand and its country of origin, and are strongly associated with American culture. In the ranking of the world's most valuable brands, Apple takes 1st place while McDonalds is 10th (Interbrand, 2018). Russell et al. (2011) note that Levi's has the fifth highest rate of "Americanism" among French consumers, in a ranking led by McDonald's - this refers to the most "American" perceived brands to the French. The product categories, in turn, fall under both those most frequently researched (computers and consumer electronics - Apple; textile/apparel/shoes - Levi's) and those least studied (services - McDonald's) (Usunier, 2006) for country of origin. The Younger Millennial generation was chosen because much of the COO literature tacitly assumes that everyone is equally influenced by the $\mathrm{COO}$ phenomenon and treats therefore all customers alike (Samiee, 2010). However, segmentation is central to developing more appropriate market planning and strategy.

\section{LITERATURE REVIEW AND HYPOTHESES DEVELOPMENT}

Roth and Diamantopoulos (2009) delimit the beginning of studies on national stereotypes and perceptions of nations to the 1930s, but only Schooler's (1965) seminal article empirically demonstrated that consumers discriminate against products that are identical except in their country of origin. This information influenced their judgment about a product. Several studies have sought antecedents on evaluations of the country of origin (Klein, Ettenson, \& Morris, 1998; Lu et al., 2016; Pharr, 2005; Rojas-Méndez, Murphy, \& Papadopoulos, 2013). The latest review of the literature on country of origin is more focused on discussion about the relevance of this research topic (Lu et al. 2016; Usunier, 2006) or moves toward new constructs, such as Country of Image (COI) (Carneiro \& Faria, 2016; Roth \& Diamantopoulos, 2009). Based on these studies, the following hypothesis was formulated:

- $\quad \mathbf{H 1}=$ Country image has a positive impact on Younger Millennials' willingness to buy brands from a country.

Based on the schema congruity theory (Mandler, 1982), Ayrosa (2002) developed a scale to measure the elements that contribute to building a country's image, composed of mainly cognitive aspects, and divided into five dimensions: a) attitudes toward products and services; b) attitudes toward the arts; c) affective responses; d) marketing; and e) importance in the global community. This scale was chosen, from many, to measure the country image, because it was translated and validated in Brazil, where the research was applied.

According to social psychology literature, stereotypes and schemas belong to the cognitive facet of attitudes. For Fishbein and Ajzen (1975), however, attitudes do not consist only of cognitive aspects but also of affective (i.e., specific feelings or emotions) and conative ones; this concept can explain favorable or unfavorable country evaluations. The mainstream research on the COO effect considers the attitudes toward a country as a univalent construct which ranges from negative to positive. The literature notes that positive/negative attitudes concerning a country may lead consumers to make positive/negative inferences about that country's product quality. Product purchases reflect this inference (Russell et al., 2011). 
BBR

17

278

Most studies on the $\mathrm{COO}$ effect, however, focus primarily on negative feelings about one or several countries (Gineikiene \& Diamantopoulos, 2017; Klein et al., 1998; Nijssen \& Douglas, 2004; Oberecker, Riefler \& Diamantopoulos, 2008; Riefler \& Diamantopoulos, 2007). However, positive views of a country can also have an impact on consumer decisions (Bartsch, Riefler, \& Diamantopoulos, 2016). The construct of country affinity captures specific, favorable feelings toward certain foreign countries and would be more influential than cognitive evaluations, for example on intentions to visit, or invest in, a country (Oberecker et al., 2008). The country affinity construct highlights the importance of a positive affective facet in shaping consumer behavior, thus complementing previous studies that focused exclusively on the behavioral implications of a negative affective facet (more notably consumer animosity) (Oberecker \& Diamantopoulos, 2011).

The country affinity concept distinguishes itself from other uses of the term affinity in the COO literature. Unlike Jaffe and Nebenzahl (2006), who viewed affinity and animosity as opposites, Oberecker et al. (2008) followed the psychological literature that shows that positive and negative affective dimensions are different, have different responses (Larsen, Mcgraw, \& Cacioppo, 2001), and should be treated independently, rather than as opposite feelings.

Although recent, the concept of a consumer's affinity for a country and that affinities influence on consumer decisions has been frequently cited in research on consumer behavior (Al Ganideh \& Al Taee, 2012; Balabanis \& Diamantopoulos, 2011; Maher, Clark, \& Maher, 2010; Sankaran \& Demangeot, 2011), although it has received criticism for a lack of empirical tests of the construct (Maher \& Carter, 2011). Based on these trends, the following hypotheses were formulated:

- $\mathbf{H}_{2}=$ Country affinity has a positive impact on Younger Millennial' willingness to buy brands from a country.

- $\mathbf{H}_{3}=$ Country image and country affinity are strongly correlated.

The Oberecker and Diamantopoulos (2011) affinity scale was chosen to measure affinity because it deals exclusively with affective aspects, unlike other scales that include cognitive aspects (e.g., Nes, Yelkur, \& Silkoset, 2014).

The study of ethnocentrism as it relates to consumer behavior (ethnocentric consumption) focuses on the issue of convenience and perceived morality during the purchase process of foreign products as well as on consumer loyalty to locally produced merchandise (Shimp \& Sharma, 1987). It works as a regulatory mechanism that can influence consumers' buying decisions, and includes affective elements, such as "sense of identity" and "sense of belonging." Several studies show that consumers with a high ethnocentric consumption level express favorable beliefs and attitudes about purchasing products developed and assembled nationally (Wong, Polonsky, \& Garma, 2008). Market globalization, in turn, is linked to an opposite and paradoxical effect: the rise of nationalism is a result of, among other causes, ethnocentrism. Global brands should be concerned about assessing, among other attributes, whether the effect of a product's country of origin is favorable for their image (Pecotich \& Ward, 2007).

US image, the focus of this study, is strongly linked to the cultural concept of the American Dream, and many global brands are in line with this image. International studies show that this image can be a dream for some consumers, but may represent a curse for others (Kapferer, 2008). Shimp and Sharma (1987) developed CETSCALE, a scale to measure ethnocentric consumption. In this paper, a reduced version of this scale featuring only five items (Oberecker $\&$ Diamantopoulos, 2011) was used to test the following hypothesis: 
- $\quad \mathbf{H}_{4}=$ Consumer ethnocentrism has a negative impact on Younger Millennial's willingness to buy non-domestic brands.

While the preponderance of mainstream research on the COO effect concerns the purchase of products made in the domestic market, or on the place where the products are made, the globalization of markets suggests that the research focus should be on international or global brands across different countries and cultures. Apple is an American company based in Silicon Valley, for example, and is one that conveys a strong message of innovation (Kapferer, 2008), even if their primary products (iPad and iPhone) are manufactured in China.

The concept of brand identity in marketing is essential to defining a brand and establishing guidelines for its management and development (Semprini, 2010). Brand identity refers to how a company sees its brand, its vision, and its essential beliefs and core values; brand image, on the other hand, is the way in which groups of consumers decode signs in the product, services, and communication disseminated by the brand (Kapferer, 2008).

Among categories of assets and liabilities that build brand equity, there are associations made about the brand, beyond perceived quality. The associations with a brand that consumers make can be identified and measured in several ways. Aaker (1997) developed a scale for measuring brand personality, based mainly on the "Big Five" set of personality traits. It opened a new field of research and increased interest in the metaphor of brand as a person, especially at a time when marketing heavily emphasized the importance of building relationships with brands (Azoulay \& Kapferer, 2003; Fournier, 1998). Although the development of the Big Five was not theorydriven, the most important personality constructs, as proposed by personality theorists as diverse as Jung (typology), Leary (interpersonal theory), Guilford (temperamental theory), and Eysenk (psycho-biological factor model), are integrated into the Big Five structure (Sanz, Gil, Garcia-Vera, $\&$ Barrasa, 2008). The concept of brand personality is important in order to increase a brand's equity (Aaker, 1991) and to differentiate it (Aaker, 1997) among the numerous offers on the market, potentially influencing consumers' purchase intentions (Keller, 1993). Wang and Yang (2008) found a strong relationship between brand personality and purchase intention in a study of automotive brands in China: the more positive the brand personality was, as measured with Aaker's scale, the higher the purchase intention. They also concluded that, if brand personality were weak, no matter the strength of the country's image, purchase intention would also be weak - that is, brand personality had more importance in their study than the country's image. The widespread use of Aaker's brand personality scale increased criticism regarding its validity (Azoulay \& Kapferer, 2003), non-generalizability (Austin, Siguaw, \& Mattila, 2003), and the non-replicability of the five factors cross-culturally (Smit, Berge, \& Franzen, 2002; Azoulay \& Kapferer, 2003).

Geuens, Weijters and De Wulf (2009) developed a new scale in response to the criticisms of brand personality scales, based only on items related to the Big Five (New Brand Personality Measure), which was used to test the following hypothesis:

- $\mathbf{H}_{5}=$ Brand personality has a positive impact on Younger Millennials' willingness to buy a global brand.

A positive brand image is built by creating robust, favorable, and unique brand associations in a consumer's memory (Keller, 1993), including user imagery and psychological benefits (Aaker, 
BBR

17

280

1991). The question of psychological benefits refers to research dealing with the meaning of possessing products and brands, along with the concept of self.

Greenwald (1988) discussed four sides of self: diffuse self, public self, private self and collective self. Each of these reflects a different ego task and is a basis for self-evaluation with a relevant audience of the self or others. Public and private facets of self are essential to understanding the role of possessions in the definition and maintenance of the adult self. In Greenwald's (1988) social-cognitive approach, the public self is characteristic of other-directed individuals, its ego task is social recognition and status, and self-esteem is the basis for others' approval. The private self, in turn, seeks individual achievement based on some personal standard, plays to private, inner audiences in support of self-worth and is characteristic of self-directed individuals (Ball \& Tasaki, 1992).

According to Fournier (1998), the relationship between a consumer and a brand can be based on meanings that are central to self-concept of the individual. For social identity theory (Huffman, Ratneshwar, \& Mick, 2000), consumer behavior is based on two central concepts: a) people act and buy products to enact identities consistent with their ideal self-image; b) people do not enact just one, but multiple identities, triggered by different social contexts within which they move (Kleine III, Kleine, \& Kernan, 1993). Brands have meaning and value not only for their ability to express themselves but also for their role in helping consumers create and build their self-identities, as well as in building connections with them (Escalas \& Bettman, 2003). In this respect, Escalas and Bettman (2003) address brands the same way that Belk (1988) treats the concept of possessions in the theory of self. Thus, a consumer builds his or her identity and presents it to others through brand choices, based on the congruence between brand image and self-image (to the extent that individuals have incorporated brands into their self-concept), which leads to the following hypotheses:

- $\quad \mathbf{H}_{\mathbf{6}}=$ The connection between consumer self and brand (self-brand connection) has a positive impact on Younger Millennials' willingness to buy global brands;

- $\quad \mathbf{H}_{7}=$ Brand personality and consumer self-brand connection are strongly correlated.

The model that represents the hypotheses is in Figure 1.

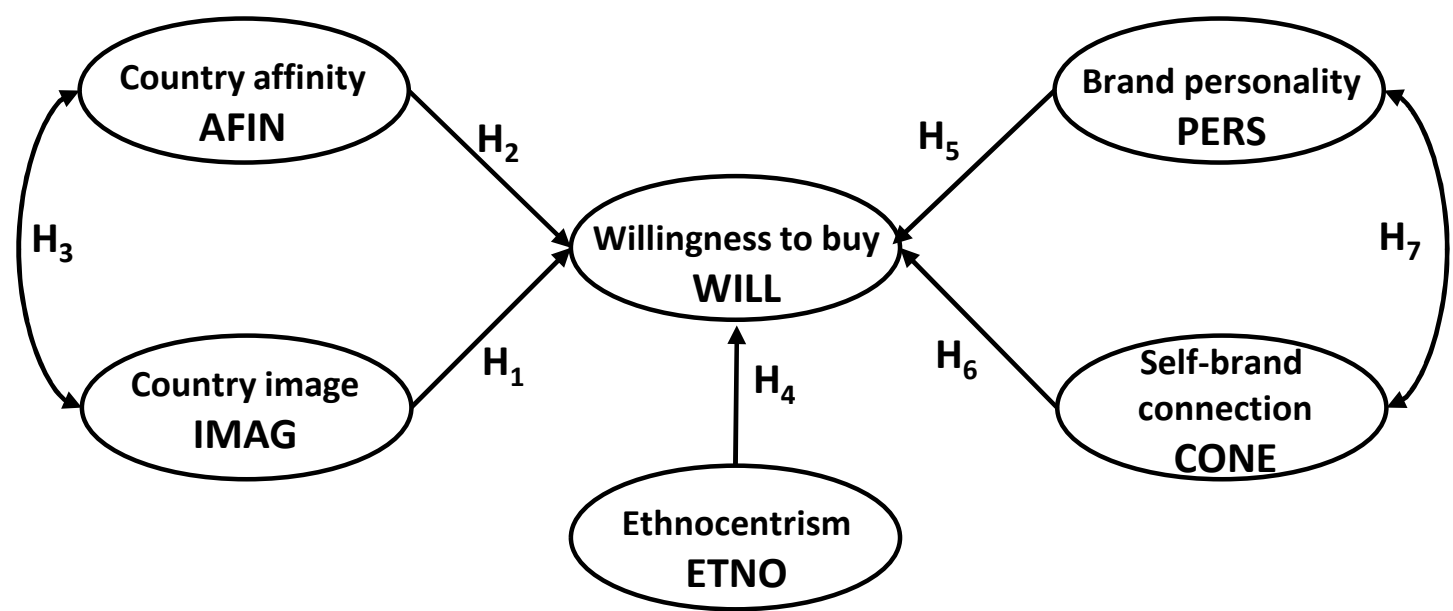

Figure 1. Hypotheses

Source: Author's elaboration. 


\section{METHOD}

The research approach was quantitative and used a non-probabilistic convenience sampling procedure. Undergraduate students were directed, in exchange for course credit, to fill out a questionnaire, under our supervision, to do fill-in questions, resulting in a sample of 401 responses from upper-middle- and high-income 17-23-year-old (Younger Millennials) from Sao Paulo, Brazil. In Brazil, the target audience for all three brands is young and middle/high income, which is different from the target audiences in other countries, especially for McDonald's and Levi's. Thus, this sample can be considered as a sample of consumers, and not an unrepresentative sample of college students, which is a limitation of several studies about brands (Buil, Martínez, \& Chernatony, 2013).

The questionnaire included age, gender and family income as control variables. Several validated and replicated scales were fully employed, without reductions (Table 1). All of them have, in their original validation studies, at least satisfactory Cronbach's alpha indexes (.60 to .94). The Younger Millennials generation was defined as in Debevec, Schewe, Madden, and Diamond (2013), as those from 17 to 23 years old.

Table 1

Constructs Operationalization

\begin{tabular}{|c|c|c|c|c|}
\hline \multicolumn{2}{|c|}{ Construct } & \multirow{2}{*}{$\begin{array}{l}\text { Theory } \\
\text { Mandler } 1982 \text { Schema } \\
\text { congruity }\end{array}$} & \multicolumn{2}{|c|}{ Scale } \\
\hline IMAG & Country Image & & Ayrosa 2002 & $\begin{array}{l}15 \text { items } \\
5 \text {-point Likert }\end{array}$ \\
\hline AFIN & Country Affinity & $\begin{array}{l}\text { Fishbein, Ajzen } 1975 \\
\text { Attitude }\end{array}$ & $\begin{array}{l}\text { Oberecker, } \\
\text { Diamantopoulos } 2011\end{array}$ & $\begin{array}{l}10 \text { items } \\
6 \text {-point intensity }\end{array}$ \\
\hline ETNO & $\begin{array}{l}\text { Ethnocentric } \\
\text { Consumption }\end{array}$ & $\begin{array}{l}\text { Shimp, Sharma } 1987 \\
\text { Ethnocentrism }\end{array}$ & $\begin{array}{l}\text { Oberecker, } \\
\text { Diamantopoulos } 2011\end{array}$ & $\begin{array}{l}5 \text { items } \\
5 \text {-point Likert }\end{array}$ \\
\hline PERS & Brand Personality & Big Five & $\begin{array}{l}\text { Geuens, Weijters, De } \\
\text { Wulf } 2009\end{array}$ & $\begin{array}{l}12 \text { items } \\
7 \text {-point intensity }\end{array}$ \\
\hline CONE & Self-brand Connection & $\begin{array}{l}\text { Huffman et al. } 2000 \\
\text { Social identity }\end{array}$ & Escalas, Bettman 2003 & $\begin{array}{l}7 \text { items } \\
\text { 5-point Likert }\end{array}$ \\
\hline WILL & Willingness to Buy & & Putrevu, Lord 1994 & $\begin{array}{l}3 \text { items } \\
\text { 5-point Likert }\end{array}$ \\
\hline
\end{tabular}

Source: Author's elaboration.

Data was collected through an online survey, and data analysis was performed for each brand separately, using Structural Equation Modeling (SEM) with IBM-SPSS AMOS ${ }^{\text {TM }} 23$ software. The estimation method used was Maximum Likelihood (ML), mostly used for SEM because it provides parameter estimates and standard errors that are consistent and efficient, showing that variables are normally distributed, the model is correctly specified, and the sample size is large enough (Schermelleh-Engel, Moosbrugger, \& Muller, 2003).

The evaluation criteria of goodness of fit (GOF) for the SEM indicate the extent to which the specified model fits empirical data (Schermelleh-Engel et al., 2003). GOF depends on the model's characteristics, such as sample size and complexity, and its assessment must include multiple levels, and measures of various kinds (Hair Jr., Black, Babin, \& Anderson, 2009). GOF evaluation was carried out by using GFI, AGFI, NFI, TLI, CFI, RMSEA, and ratio chi-square/ degrees of freedom. 
BBR

17

282

\section{RESULTS AND ANALYSIS}

From the initial 401 questionnaires, those not filled out completely were discarded (34), resulting in 367 valid questionnaires for analysis - enough sample size to run the SEM (Hair Jr. et al., 2009). Missing data, outliers, normality, and multicollinearity were approached, and no problems were found.

All the respondents knew Apple, McDonald's and Levi's and identified them as brands from the United States. These students either did not work at all (82.3\%) or were doing an internship or part-time work $(9.0 \%)$. The demographic profile of the sample features a predominance of women (54.0\%), which is in line with the Brazilian undergraduate student profile; $72.8 \%$ of students were 19 years old or younger and from high- or upper-middle-income families. This profile configures a homogeneous group of young people dedicated to the study: those with little connection to professional life, who live with their parents and can afford the brands used in the study, more expensive in Brazil than in the United States (Cunha, Moraes, Rocha, \& Strehlau, 2017).

To build SEM more accurately, an exploratory factor analysis (EFA) was developed to check how well measured variables performed in comparison with theory. EFA was conducted for each of the constructs related to the country (country image, country affinity, and ethnocentrism) and to the brand (self-brand connection, brand personality), and willingness to buy. The method used was the principal component, based on a correlation matrix with Varimax rotation and extraction of factors with eigenvalues higher than one, checking the percentage of explained variance and reliability (Cronbach's alpha). The factor loadings considered were all above .50 (Hair Jr. et al., 2009). The criterion for acceptance was a Cronbach's alpha above .60 (Hair Jr. et al., 2009), and all scales went above .75 .

The results for GOF are shown in Table 2 , and it was good only for RMSEA and $\chi^{2} /$ d.f., resulting in levels below acceptable for all other indicators. However, the values are considered close to the minimum criteria for acceptance. Additionally, the sample size and complexity of the model had negative impacts on these indices (Hair Jr. et al., 2009). Therefore, the overall measurement model has a reasonable (though not high) degree of compatibility with the empirical data.

Table 2

Goodness of Fit (GOF)

\begin{tabular}{lcccccc}
\hline & \multicolumn{2}{c}{ Criterion $^{a}$} & & & & \\
\cline { 2 - 5 }$\chi^{2}$ & Acceptable fit & Good fit & Apple & Levi's & McDonald's & Result \\
DF & & & 1454.57 & 1424.09 & 1533.12 & \\
$\chi^{2 / \mathrm{DF}}$ & $2<\chi 2 / \mathrm{df} \leq 3$ & $0<4$ & 884 & 884 & \\
GFI & $.90 \leq \mathrm{GFI}<.95$ & $.95 \leq \mathrm{GFI} \leq 1.00$ & .85 & .85 & .84 & Below \\
AGFI & $.85 \leq \mathrm{AGFI}<.90$ & $.90 \leq \mathrm{AGFI} \leq 1.00$ & .83 & .83 & .82 & Below \\
NFI & $.90 \leq \mathrm{NFI}<.95$ & $.95 \leq \mathrm{NFI} \leq 1.00$ & .79 & .82 & .80 & Below \\
TLI & $.95 \leq \mathrm{TLI}<.97$ & $.97 \leq \mathrm{TLI} \leq 1.00$ & .90 & .92 & .89 & Below \\
CFI & $.95 \leq \mathrm{CFI}<.97$ & $.97 \leq \mathrm{CFI} \leq 1.00$ & .90 & .92 & .90 & Below \\
RMSEA & $.05<\mathrm{RMSEA} \leq .08$ & $0 \leq \mathrm{RMSEA} \leq .05$ & .042 & .041 & .454 & Good \\
\hline
\end{tabular}

a Schermelleh-Engel, Moosbrugger, Muller, 2003

Source: Author's elaboration. 
The Goodness of Fit Index (GFI) is the measure of how much the model adjusts when compared to a null model, in which all parameters are set to zero (Schermelleh-Engel et al., 2003). The values obtained in the model are below the criterion, indicating that the model does not fully explain the sample $(.85 / .85 / .84<.90)$. The AGFI (Adjusted Quality of Adjustment Index), which is the GFI adjusted by the number of degrees of freedom, presented results close to the acceptance criterion $(.83 / .83 / .82<.85)$, indicating that the model benefits from a large sample size, but is penalized for its complexity. The Normed Fit Index (NFI) is an incremental adjustment index derived from the comparison between the hypothetical and the independent models and indicates whether the hypothetical model is the best possible improvement over the independent model (Schermelleh-Engel et al., 2003). The obtained results $(.79 / .82 / .80<.90)$ are far from the criterion of acceptance, pointing to a poor improvement of the studied model to the independent model. The Tucker-Lewis Index (TLI or NNFI) takes the degrees of freedom of the specified model, as well as the degrees of freedom of the independence model, into consideration. The results can be considered good, despite being below the criterion $(.90 / .92 / .89<.95)$, because more complex models, like this one, are penalized by a downward adjustment. The TLI advantage is that it is one of the fit indices less affected by sample size. As for the Comparative Fit Index (CFI), the results were below the acceptance criterion $(.90 / .92 / .90<.95)$. However, Hair Jr. et al. (2009) state that values below 0.95 do not necessarily indicate that the fit of this model is not proper for improvement over the independent model.

The last adjustment index is the Root Mean Square Error of Approximation (RMSEA), one of the most informative criteria for modeling in covariance structures, and which best represents how well a model adjusts to a population and not just to a sample used for estimation (Hair Jr. et al., 2009). The evaluated model had values within the criterion of a good fit, indicating that the model fits well to the population, even if it does not fully explain the sample, as indicated by the GFI and the AGFI.

The path diagram is represented in Figure 2 (Apple as an example).

SEM results (Table 3) show that the major force boosting intention to buy is the self-brand connection (WILL $\leftarrow$ CONE = .66 Apple / .79 Levi's / .59 McDonald's), which is statistically significant, with a value of $p<.001$. Brand personality has a positive impact for all brands (WILL $\leftarrow$ PERS $=.13$ Apple / .06 Levi's / .11 McDonald's), but the results were statistically significant only for Apple $(p=.05)$.

Regarding a country's influence on willingness to buy, the results differ depending on the brand. For Apple, country affinity had a positive and statistically significant result (WILL $\leftarrow$ AFIN = $.14 ; p=.01$ ), which did not happen for the other two brands. On the other hand, country image (IMAG) had no effect on willingness to buy (WILL) for any of the brands. This fact may suggest that the COO has no direct effect on the Younger Millennials willingness to buy global brands.

As expected, ethnocentrism had a negative impact on willingness to buy for all three brands (WILL $\leftarrow$ ETNO = -.05 Apple / -.04 Levi's / -.04 McDonald's), although the effect is weak and not statistically significant $(p=.38, .36$ and .40 , respectively). 
BBR

17

284

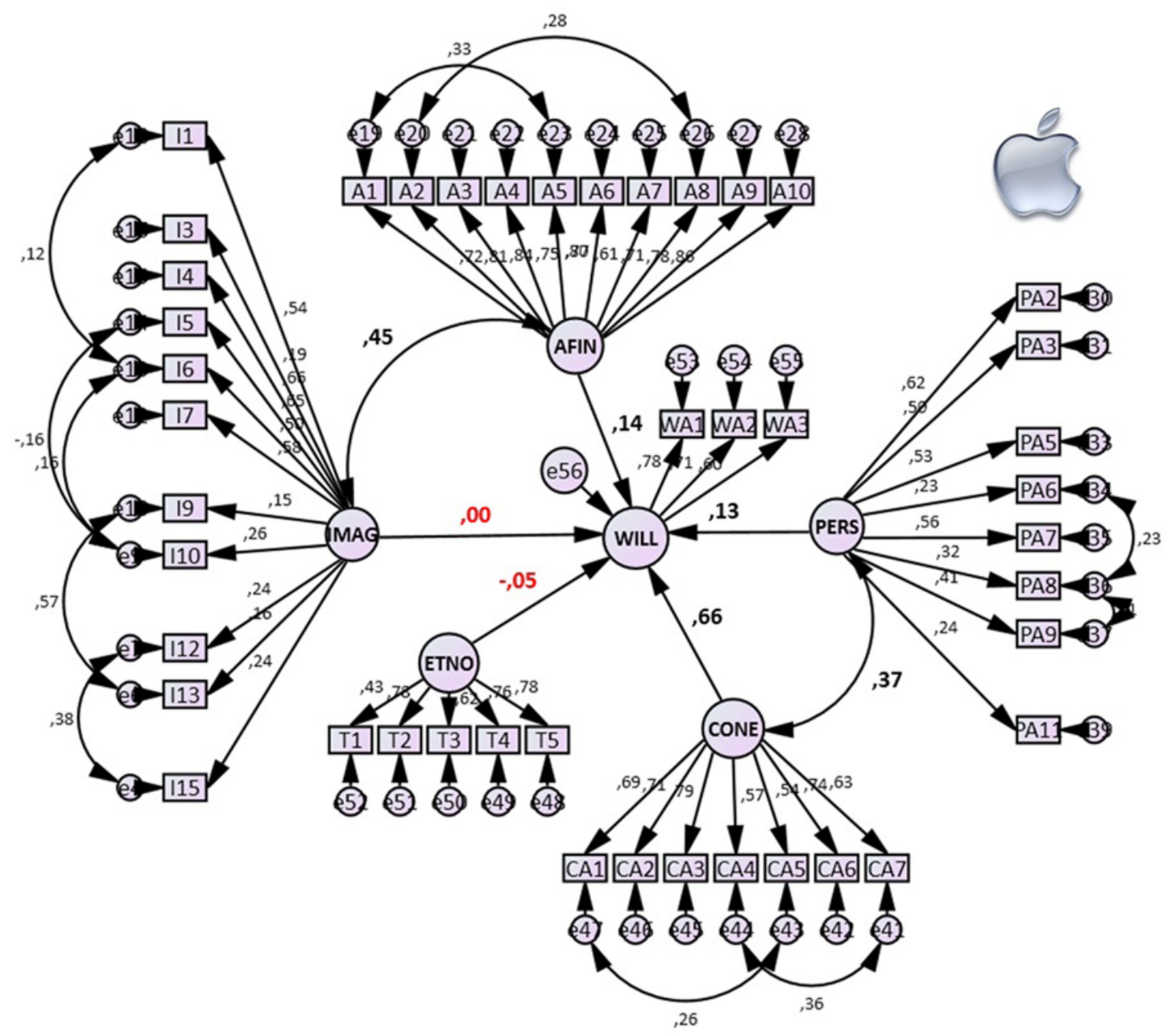

Figure 2. Path Diagram (Apple)

Source: Author's elaboration.

Our results did not provide complete empirical support for $\mathrm{H}_{1}$ (WILL $\leftarrow$ IMAG), $\mathrm{H}_{2}$ (WILL $\leftarrow$ AFIN), and $\mathrm{H}_{4}($ WILL $\leftarrow$ ETNO), contrary to the literature about $\mathrm{COO}-$ in fact, the results seem to show that the importance of COO depends on the brand.

The correlation between country image and country affinity (IMAG $\leftrightarrow$ AFIN $=.45, p<0.001$, for the three brands) is in line with Nes et al., (2014), whose scale included both cognitive (country image) and affective aspects (country affinity).

Support of hypotheses 3 and 7 characterize the proposed model as having two sides - a country side and a brand side, the latter being the one with stronger results regarding influence on willingness to buy. Figure 3 shows the results of the hypothesis test in the research model graphical representation. 
Table 3

Hypotheses Testing

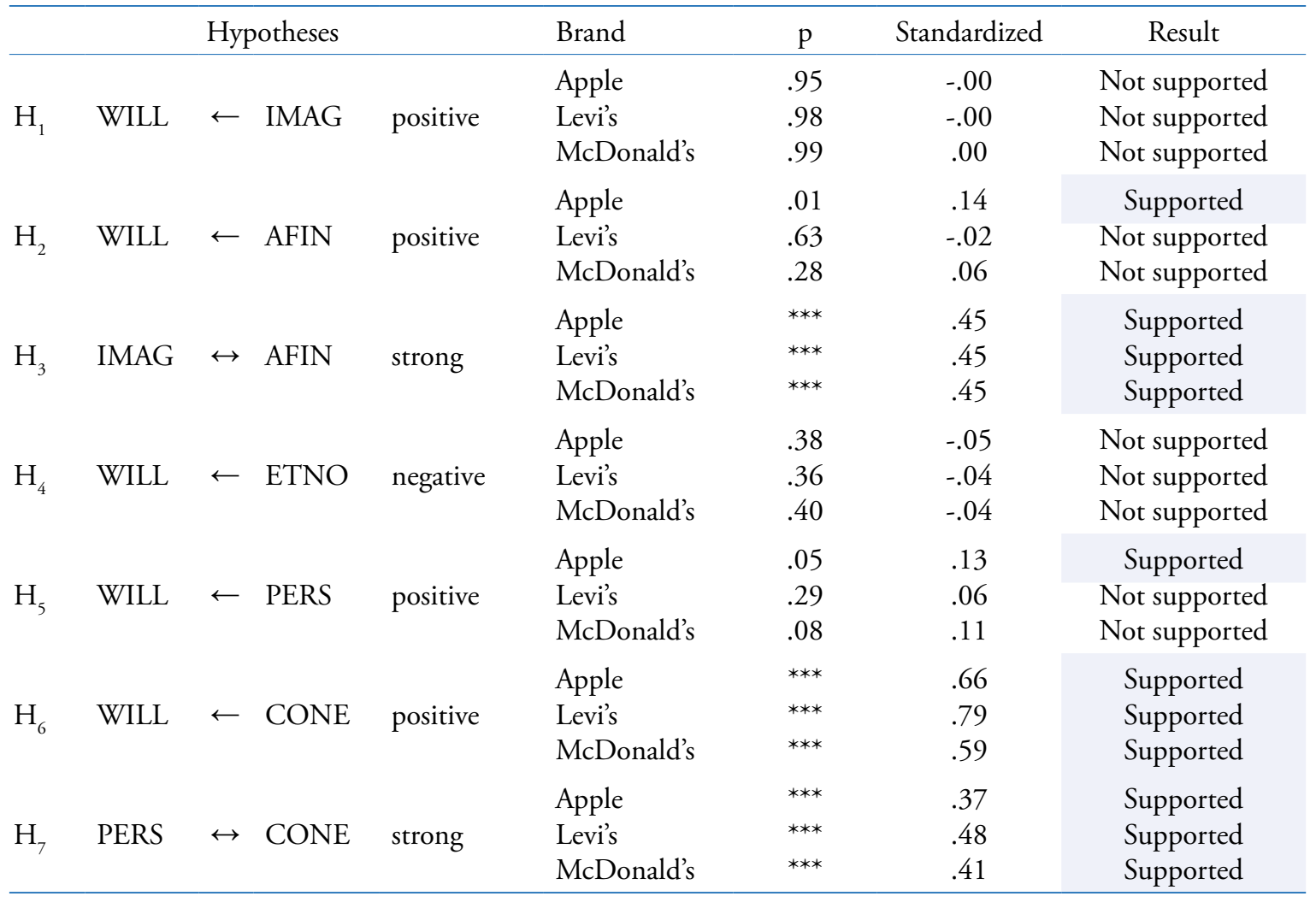

**** $<.001$

Source: Author's elaboration.

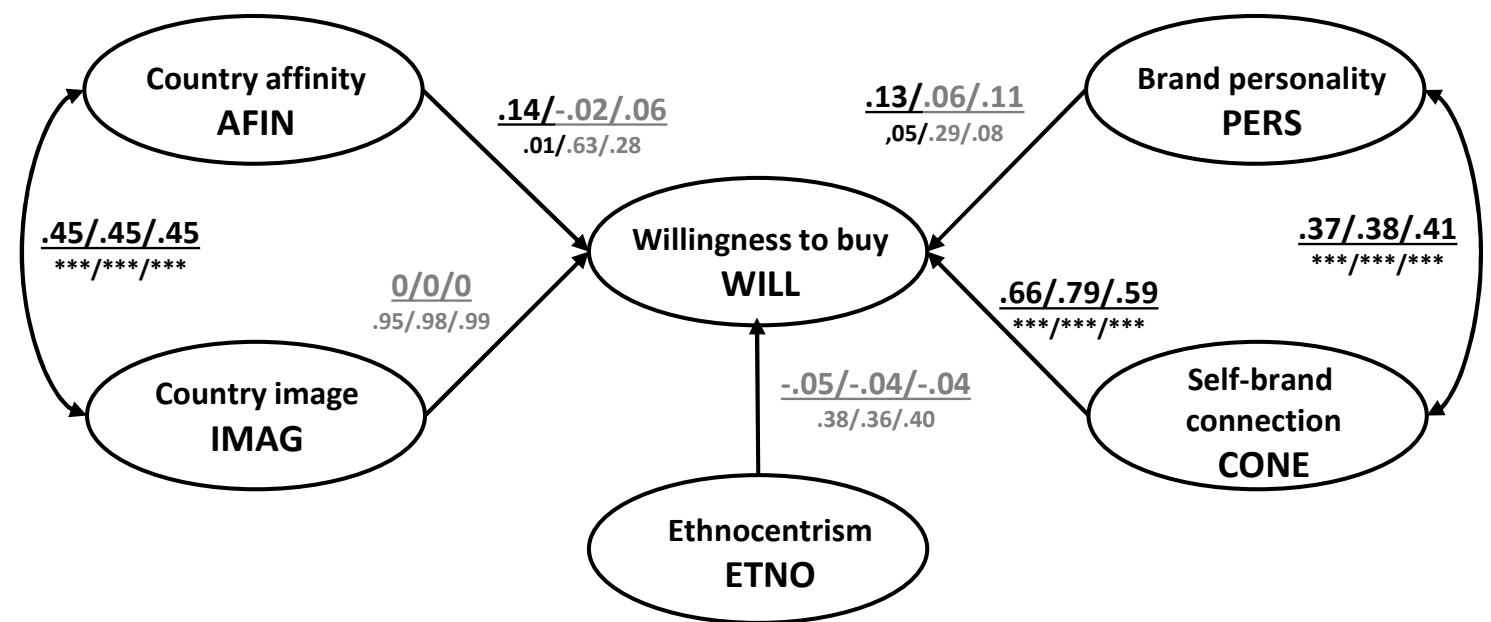

Figure 3. Hypothesis test results (Apple/ Levi's/McDonald's)

Source: Author's elaboration. 


\section{DISCUSSION AND CONCLUSIONS}

The results showed differences between country and brand on Younger Millennials' willingness to buy global brands from the USA. The impact of the brand side of the model on willingness to buy (personality and mainly self-brand connection) was not only positive and statistically significant (or close to it) but also much stronger than that related to the country of origin (H6 supported; H5 supported for Apple, close to it for McDonald's). Consistent with these results, most surveys have found that consumers tend to separate political opinions from purchasing habits; those who protest against globalization and capitalism in front of McDonald's restaurants sometimes wear Levi's jeans (Lindberg \& Nossel, 2005).

On the other hand, the results did not show any relevant impact of the country side of the model (affinity, image, and ethnocentrism) on the willingness to buy, except for country affinity for Apple (H1 not supported, H2 supported for Apple). This may suggest that the COO has no direct influence on the Younger Millennials willingness to buy global brands. Instead, the effect of country image and affinity could be mediated by brand image.

Self-brand connection is important in building Younger Millennials' purchase intention. Indeed, this is the most important element identified by the model. Brand expresses who the individual is, both to himself and to others, and this identification is directly related to high purchase intention. Apple and Levi's, for example, have an important component of visibility; they are widely used in public, which directly influences the other-oriented individuals. McDonald's also has this character of visibility, not only because its consumption is observable but also because it can be carried out in groups. According to Greenwald (1988), the primary task of the public-self's ego is recognition and status, and the approval of others provides the basis for self-esteem. The use of the brands studied in this paper aligns with this.

Traditional COO studies have always used samples not segmented by generation. Schooler (1965), who empirically demonstrated that consumers discriminated against products according to their COO, used a sample of students at the time, and actually researched the behavior of the Baby Boomer generation. The behavior of this generation became the paradigm that always supported the concept of the COO effect. More recent studies, when trying to reproduce the population profile in their samples, do not represent significant differences in behavior concerning the paradigm defined more than 50 years ago. Diamantopoulos et al. (2011), for example, demonstrated the mediation of the brand in the COO effect with a sample of 404 British who represented the country's population in terms of gender and age, ranging from 18 to 65+ years without discriminating youths behavioral differences. In another study, Carneiro \& Faria (2016) defined the conceptual domain and the level of analysis of country image that would be relevant for a given research setting with a sample of 315 elements, that is representative of consumers population, from under 20 years old, to 70 or more, not discriminating different segments also.

The COO effect, then, would be less powerful than the effect of a brand, at least regarding global brands with high equity and younger generations, such as studied here. Thus, the country image construct, intensely studied in the international marketing literature, can be fragile in the face of strong and well-built brands, especially for Younger Millennials. Thus, it was possible to conclude that research designed to carry out studies aiming to measure $\mathrm{COO}$ effect on purchase intentions or product image-building, without the mediation of the brand and the moderation of generations, is no longer appropriate. In this respect, Diamantopoulos et al. (2011) show that research on the $\mathrm{COO}$ effect has been predominantly product-centric, matching certain countries 
with specific product categories; however, brand image also needs to be considered explicitly in this type of research. Riefler (2012) adds that both brand globality and brand origin are relevant for global brand studies, especially for Younger Millennials, that are a more difficult target to engage with advertising campaigns (Kantar, 2017).

\section{CONTRIBUTIONS AND LIMITATIONS}

From a theoretical and empirical standpoint, this study is in line with recent research on the $\mathrm{COO}$ effect, which indicates that country of origin of the brand could be more important to consumers than the country of origin of the product (Usunier, 2006). Apple is an American brand, even if the iPod is manufactured in China; Levi's is an American jeans brand, even if the last U.S. plant in San Antonio was closed in 2004 (Levi, 2010); McDonald's is American, too, even if all the ingredients, packaging and processes originate in the country wherein the meals are consumed. In addition, the literature seems to treat all consumers as equals and tacitly assumes that the country of origin effect would influence (or not) all of them. To address the issue of market segmentation, consumers that fit the profile of a brand's target audience were interviewed (Younger Millennials). Another contribution was to study a case from the service sector, which is not very common in research on the COO (Usunier, 2006).

The main managerial contribution of this study is the importance of the self-brand connection that emerged from the model. It may lead to robust brand attitudes, that is, attitudes that are not very susceptible to change. Consumers who have used brand associations to construct their selfidentities may be more forgiving of marketer blunders, more brand loyal, and less likely to switch to competing brands, providing the brand an enduring competitive advantage, because this type of connection is difficult for competitors to imitate (Escalas \& Bettman, 2003). Therefore, the notion that Younger Millennials consumers form a bond with a brand, as they use its associations for self-construction, is important to marketing managers for guiding strategic communications decisions, mainly to build strong competences in: a) experiential marketing activities that provide sensory, emotional, cognitive, behavioral, and relational values that replace functional values (Schmitt, 1999); and b) social networking sites (SNS), mainly if global brands are targeting younger audiences who are more likely to display SNSs prominently on their homepages and use SNSs to ask consumers to share brand content, or engage with a brand community (Araujo \& Neijens, 2012).

This finding answers some questions raised by Usunier (2006) about whether the research on the COO effect still makes sense for business, whether consumers still give importance to the country where a product is manufactured and if this field of research would provide managers with analysis and recommendations relevant to marketing decisions. Brand and individual connection would be the key influencer of purchase intention, rather than country of origin, at least for Younger Millennials.

The study has limitations. The first one is the lack of sample representativeness that prevents the findings from being generalized to a population. Secondly, the model built for analysis did not reach a GOF that can be classified as good but was close to an acceptable level when compared to null and independent models. Mainly, the model represents not only the sample but also the population. Finally, all the brands studied were high brand equity ones, which may restrict the scope of the conclusions. 
On that point, the first recommendation for future studies emerges: to investigate low brand equity brands. Second, brands that are not emblematic of a country could also be studied. Finally, the model could be applied to other countries, product categories, and brands.

\section{REFERENCES}

Aaker, D. (1991). Managing Brand Equity. New York: Fee Press.

Aaker, J. (1997). Dimensions of brand personality. Journal of Marketing Research, 34, 3, 342-352.

Akram, A., Merunka, D., \& Akram, M. S. (2011). Perceived brand globalness in emerging markets and the moderating role of consumer ethnocentrism. International Journal of Emerging Markets, 6, 4, 291-303.

Al Ganideh, S. F., \& Al Taee, H. (2012). Examining Consumer Ethnocentrism amongst Jordanians from an Ethnic Group Perspective. International Journal of Marketing Studies, 4, 1, 48-57.

Araujo, T., \& Neijens, P. (2012). Friend me: which factors influence top global brands participation in social network sites. Internet Research, 22, 5, 626-640.

Austin, J. R., Siguaw, J. A., \& Mattila, A. S. (2003). A re-examination of the generalizability of the Aaker brand personality measurement framework. Journal of Strategic Marketing, 11, 77-92.

Ayrosa, E. A. T. (2002). Validation of a scale to measure country image in Brazil. The Business Association of Latin American Studies Annual Conference - 2002 (BALAS).

Azoulay, A., \& Kapferer, J. N. (2003). Do brand personality scales really measure brand personality? Brand Management, 11, 2, 143-155.

Balabanis, G., \& Diamantopoulos, A. (2011). Gains and Losses from the Misperception of Brand Origin: The Role of Brand Strength and Country-of-Origin Image. Journal of International Marketing, 19, 2, 95-116.

Ball, A. D., \& Tasaki, L. H. (1992). The role and measurement of attachment in consumer behavior. Journal of Consumer Psychology, 1, 2, 155-172.

Bartsch, F., Riefler, P., \& Diamantopoulos, A. (2016). A Taxonomy and Review of Positive Consumer Dispositions Toward Foreign Countries and Globalization. Journal of International Marketing, 24 (1), 82-110.

Belk, R. W. (1988). Possessions and the extended self. Journal of Consumer Research, 15, 139-168.

Buil, I., Martínez, E., \& Chernatony, L. (2013). The influence of brand equity on consumer responses. Journal of Consumer Marketing, 30, 1, 62-74.

Carneiro, J., \& Faria, F. (2016). Quest for purposefully designed conceptualization of the countryof-origin image construct. Journal of Business Research, 69, 10, 4411-4420.

Cunha, R. D., Moraes, S. G., Rocha, T., \& Strehlau, V. I. (2017). Glocal prices as a strategic component to brand positioning. Proceedings 26th Annual CiMaR - Conference Consortium for International Marketing Research, 2017, Florence

Debevec, K., Schewe, C., Madden, T., \& Diamond, W. (2013). Are today's Millennials splintering into a new generational cohort? Maybe! Journal of Consumer Behaviour, 12, 1, 20-31.

Diamantopoulos, A., Schlegelmilch, B., \& Palihawadana, D. (2011). The relationship between country-of-origin image and brand image as drivers of purchase intentions: A test of alternative perspectives. International Marketing Review, 28, 5, 508-524. 
Escalas, J. E., \& Bettman, J. R. (2003). You Are What They Eat: The Influence of Reference Groups on Consumer Connections to Brands. Journal of Consumer Psychology, 13, 3, 339-348.

Fishbein, M., \& Ajzen, I. (1975). Belief, attitude, intention and behavior, an introduction to theory and research. Reading: Addison-Wesley.

Fournier, S. (1998). Consumers and their brands: Developing relationship theory in consumer research. Journal of Consumer Research, 24, 343-373.

Geuens, M., Weijters, B., \& De Wulf, K. (2009). A new measure of brand personality. International Journal of Research in Marketing, 26, 2, 97-107.

Gineikiene, J., \& Diamantopoulos, A. (2017). I hate where it comes from, but I still buy it: Countervailing influences of animosity and nostalgia. Journal of International Business Studies, $48,8,992-1008$.

Greenwald, A. G. (1988). A Social-Cognitive Account of the Self's Development. In Lapsley, D. K., \& Power, C. (Eds) Self, Ego, and Identity: Integrative Approaches. New York: Springer Verlag, 30-42.

Hair Jr., J. F., Black, W. C., Babin, B. J., \& Anderson, R. E. (2009). Multivariate Data Analysis. 7th Edition. Upper Saddle River: Prentice Hall.

Huffman, C., Ratneshwar, S., \& Mick, D. G. (2000). Consumer goal structures and goal-determination processes: An integrative framework. In Ratneshwar S., Mick, D. G., \& Huffman, C. (Eds.). The why of consumption: Contemporary perspectives on consumer motives, goals, and desires. New York: Routledge, 9-35.

Interbrand (2018). 2018 Ranking of the Top 100 Brands. Retrieved January 08, 2019, from https:// www.interbrand.com/best-brands/best-global-brands/2018/ranking/

Jaffe, E. D., \& Nebenzahl, I. D. (2006). It's All in the Eyes of the Consumer. In National Image \& Competitive Advantage: The Theory and Practice of Place Branding. Copenhagen: Narayana Press, 79-109.

Kantar Millward Brown (2017). AdReaction: Engaging Gen X, Y and Z [PDF file]. Retrieved January 21, 2018, from https:/www.iabeurope.eu/wp-content/uploads/2017/05/AdReaction-Gen-X-Yand-Z_Global-Report_FINAL_Jan-10-2017.pdf.

Kapferer, J. N. (2008). The New Strategic Brand Management: Creating and Sustaining Brand Equity Long Term, 4 ed. London: Kogan Page.

Keller, K. L. (1993). Conceptualizing, measuring and managing customer-based brand equity. Journal of Marketing, 57, 1-22.

Klein, J., Ettenson, R., \& Morris, M. (1998). The animosity model of foreign product purchase: an empirical test in the People's Republic of China. Journal of Marketing, 62, 89-100.

Kleine III, R. E., Kleine, S. S., \& Kernan, J. B. (1993). Mundane consumption and the self: A socialidentity perspective. Journal of Consumer Psychology, 2, 3, 209-236.

Larsen, J. T., McGraw, A. P., \& Cacioppo, J. T. (2001). Can People Feel Happy and Sad at the Same Time? Journal of Personality \& Social Psychology, 81, 4, 684-696.

Levi Strauss \& Co (2010). Annual Report. Retrieved February 14, 2014, from http://lsco.s3.amazonaws. com/wp-content/uploads/2014/01/2010-Annual-Report.pdf.

Lindberg, T., \& Nossel, S. (2005). Report of the Working Group on Anti-Americanism. The Princeton Project on National Security. Retrieved February 2, 2014, from http://www.princeton.edu/ ppns/ conferences/reports/fall/AA.pdf. 
BBR

17

290

Lu, I., Heslop, L., Thomas, D., \& Kwan, E. (2016). An examination of the status and evolution of country image research. International Marketing Review, 33, 6, 825-850.

Magnusson, P., Westjohn, S. A., \& Zdravkovic, S. (2011). "What? I thought Samsung was Japanese": accurate or not, perceived country of origin matters. International Marketing Review, 28, 5, 454-472.

Maher A. A., \& Carter, L. L. (2011). The affective and cognitive components of country image: perceptions of American products in Kuwait. International Marketing Review, 28, 6, 559-580.

Maher, A. A., Clark, P., \& Maher, A. (2010). International consumer admiration and the persistence of animosity. Journal of Consumer Marketing, 27, 5, 414-424.

Mandler, G. (1982). The Structure for Value: Accounting for Taste. In Clarke, M. S., Fiske, S. T. (Eds). Affect and Cognition: The 17th Carnegie Symposium on Cognition. Hillsdale: Erlbaum, 3-36.

Martin, D. (2007). Rebuilding brand America. AMACOM (American Management Association). Retrieved November 2, 2013, from http://books.google.com.br/books?id=1N0HjMi0oPoC\&source=gbs_ navlinks_s.

Nes, E. B., Yelkur, R., \& Silkoset, R. (2014). Consumer affinity for foreign countries: Construct development, buying behavior consequences and animosity contrasts. International Business Review, 23, 4, 774-784.

Nijssen, E. J. \& Douglas, S. P. (2004). Examining the animosity model in a country with a high level of foreign trade. International Journal of Research in Marketing, 21, 23-38.

Oberecker, E. M., \& Diamantopoulos, A. (2011). Consumers' Emotional Bonds with Foreign Countries: Does Consumer Affinity Affect Behavioral Intentions? Journal of International Marketing, $19,2,45-72$.

Oberecker, E., Riefler, P., \& Diamantopoulos, A. (2008). The Consumer Affinity Construct: Conceptualization, Qualitative Investigation, and Research Agenda. Journal of International Marketing, 16, 3, 23-56.

Pecotich, A. \& Ward, S. (2007). Global Branding, country of origin and expertise: An experimental evaluation. International Marketing Review, 24, 3, 271-296.

Pharr, J. M. (2005). Synthesizing country-of-origin research from the last decade: is the concept still salient in an era of global brands? Journal of Marketing Theory and Practice, 13, 4, 34-45.

Putrevu, S., \& Lord, K. R. (1994). Comparative and Noncomparative Advertising: Attitudinal Effects under Cognitive and Affective Involvement Conditions. Journal of Advertising, 23, 2, 77-90.

Riefler, P. (2012). Why consumers do (not) like global brands: The role of globalization attitude, GCO and global brand origin. International Journal of Research in Marketing, 29, 25-34.

Riefler, P., \& Diamantopoulos, A. (2007). Consumer animosity: a literature review and a reconsideration of its measurement. International Marketing Review, 24, 1, 87-119.

Rojas-Méndez, J. I, Murphy, S. A., \& Papadopoulos, N. (2013). The U.S. brand personality: A Sino perspective. Journal of Business Research, 66, 1028-1034.

Roth, K., \& Diamantopoulos, A. (2009). Advancing the country image construct. Journal of Business Research, 62, 726-740.

Roth, K., \& Diamantopoulos, A. (2010). Advancing the country image construct: Reply to Samiee's (2009) commentary. Journal of Business Research, 63, 446-449. 
Russell, C., Russell, D., \& Klein, J. (2011). Ambivalence toward a country and consumers' willingness to buy emblematic brands: The differential predictive validity of objective and subjective ambivalence measures on behavior. Marketing Letters, 22, 357-371.

Samiee, S. (2010). Advancing the country image construct - A commentary essay. Journal of Business Research, 63, 442-445.

Samiee, S. (2011). Resolving the impasse regarding research on the origins of products and brands. International Marketing Review, 28, 5, 473-485.

Samiee, S., Shimp, T. A., \& Sharma, S (2005). Brand Origin Recognition Accuracy: Its Antecedents and Consumers' Cognitive Limitations. Journal of International Business Studies, 36, 4, 379-397.

Sankaran, K., \& Demangeot, C. (2011). On becoming a culturally plural consumer. Journal of Consumer Marketing, 28, 7, 540-549.

Sanz, J., Gil, F., Garcia-Vera, M. P., \& Barrasa, A. (2008). Needs and cognition/behavior patterns at work and the Big Five: An assessment of the personality and preference inventory-normative (PAPI-N) from the perspective of the five-factor model. International Journal of Selection and Assessment, 16, 1, 46-58.

Schermelleh-Engel, K., Moosbrugger, H., \& Muller, H. (2003). Evaluating the fit of structural equation models: Tests of significance and descriptive goodness-of-fit measures. Methods of Psychological Research Online, 8, 2, 23-74.

Schmitt, B. (1999). Experiential Marketing. Journal of Marketing Management, 15, 1-3, 53-67.

Schooler, R. D. (1965). Product Bias in the Central American Common Market. Journal of Marketing Research, II, 394-397.

Semprini, A. (2010). A marca pós-moderna: poder e fragilidade da marca na sociedade contemporânea, [The brand, a fragile power]. São Paulo: Estação das Letras e Cores.

Shimp, T. A., \& Sharma, S. (1987). Consumer ethnocentrism: construction and validation of the CETSCALE. Journal of Marketing Research, XXIV, 280-289.

Smit, E. G., Berge, E. V. D., \& Franzen, G. (2002). Brands are just like real people! The development of SWOCC's brand personality scale. In Hansen, F., Christensen, L. B. (Eds.). Branding and Advertising. Copenhagen: Copenhagen Business School Press, 22-43.

Swoboda, B., Pennemann, K., \& Taube, M. (2012). The Effects of Perceived Brand Globalness and Perceived Brand Localness in China: Empirical Evidence on Western, Asian, and Domestic Retailers. Journal of International Marketing, 20, 4, 72-95.

Usunier, J-C. (2006). Relevance in business research: the case of country-of-origin research in marketing. European Management Review, 3, 60-73.

Usunier, J-C. (2011). The shift from manufacturing to brand origin: suggestions for improving COO relevance. International Marketing Review, 28, 5, 486-496.

Wang, X., \& Yang, Z. (2008). Does country-of-origin matter in the relationship between brand personality and purchase intention in emerging economies? Evidence from China's auto industry. International Marketing Review, 25, 4, 458-474.

Wong, C. Y., Polonsky, M. J., \& Garma, R. (2008). The impact of consumer ethnocentrism and country of origin sub-components for high involvement products on young Chinese consumers product assessments. Asia Pacific Journal of Marketing and Logistics, 20, 4, 455-478. 
BBR

17

292
Zbib, I. J., Wooldridge, B. R., Ahmed, Z. U., \& Benlian, Y. (2010). Purchase of global shampoo brands and the impact of country of origin on Lebanese consumers. Journal of Product \& Brand Management, 19, 4, 261-275.

Zdravkovic, S. (2013). Does country-of-origin matter to Generation Y? Young Consumers, 14, 1, 89-102.

\section{AUTHORS CONTRIBUTIONS}

The first author contributed mainly with problem definition, hypotheses development, method, results and analysis. The second author contributed mainly with objectives, literature review, discussion and conclusions.

\section{CONFLICTS OF INTEREST}

The authors state that there are no conflicts of interests. 